\title{
Deaccessioning and collections development in Finnish museums
}

\author{
Minna Sarantola-Weiss \& Emilia Västi
}

\begin{abstract}
In 2014-16, six Finnish museums carried out a project to investigate how deaccessioning is practised in Finnish museums and how the related process could be developed. The Finnish Museums Association published two reports in Finnish on the results of the project, Kokoelmapoistojen hyvät käytännöt (2015) and Kokoelmapoistojen yhteiset käytännöt (2016), and Deaccessioning: Sharing Experiences from Finland in English in 2016. The reports discuss issues of deaccessioning and present a proposed procedure that museums can apply when considering their own deaccessioning practices. The first-mentioned publication Kokoelmapoistojen hyvät käytännöt, on good deaccessioning practice, also contains a model process. The following text is a presentation of the project and its main results.
\end{abstract}

Keywords: Collections management, deaccessioning, disposal, division of tasks in collecting, significance analysis.

The breakthrough of the "new nuseology" has led museums to pose fundamental questions regarding the significance of object collections in general, and in particular the communities whose identity the collections are regarded as reflecting or who own the collections, for example in the role of taxpayers. At the same time, the operating environment has led to considering collections from the perspectives of economy and, for example, usability and collections logistics, since issues of money and management of premises and property have become prominent aspects of everyday life in the professional running of museums. Internetbased collections management systems have, in turn, clearly improved opportunities to manage the collections of individual museums and to share information on collections among museums. For these reasons, collections management is undergoing change in the 2010s not only in terms of content and relations with users, but also, and fundamentally, with regard to the upkeep and logistics of collections. Developments in public finances are also leading in this direction. In many countries, they have caused the deterioration and even crises of the economic basis of museums.

These developments and their impact on everyday collections work formed the background when the Helsinki City Museum, the Historical Collections of the Tampere Museums and the Museum of Technology launched their deaccessioning project in 2014. We aimed at the first Finnish overview 
of how material is deaccessioned in Finnish museums of cultural history and how this process could be developed on the basis of the ICOM Code of Ethics. We wanted to discuss the philosophy of deaccessioning and the various processes associated with it. We soon noticed that many questions were worth considering together with art museums. As a result, a further project was launched in 2015 involving three art museums, HAM - Helsinki Art Museum, the Tampere Art Museum and the Aboa Vetus \& Ars Nova Museum of history and contemporary art in Turku. This second stage of the project included discussions on the special features of deaccessioning from art collections and whether they have any need in general to deaccession material. A particular distinction between cultural-historical collections and art collections concerns issues of copyright, while there are of course other differences as well. Although at present the size of art museum collections and their need for space cannot be compared to the problems faced by museums of cultural history, they, too, will pose a challenge to museum resources before long. ${ }^{1}$

Our deaccessioning project was launched at a stage when collections-related work has been developed in highly active ways in Finnish museums. Various procedures and tools have been developed in recent years that will also be useful for developing deaccessioning practices. During the 2010s museums of cultural history have created a network for collections management collaboration (the TAKO network), within which museums agree to a nationwide division of tasks in collecting. The related agreement with the National Board of Antiquities on collecting and documentation has been signed by more than a hundred professionally managed Finnish museums. There are some 150 professionally managed museums that are (partly) funded by 133 the state, which means that the network can truly coordinate accessions in professionally run museums. ${ }^{2}$ The division of collecting tasks can increase knowledge of the contents of collections and of the ways in which the museums wish to develop them. These aims are also served by the FINNA portal of all Finish memory organisations, through which both the public and museum professionals can study the cultural heritage collected and stored by museums, archives and libraries. ${ }^{3}$ A checklist for museum collections management policy (Ekosaari et al.) was published in 2013 (2014 in English) with the aim of supporting museums in preparing collections management policies. The significance analysis tool published in 2015 by the Metropolia University of Applied Sciences and Lusto - The Finnish Forest Museum is, in turn, an aid for museums for assessing and evaluating individual objects and whole collections (Häyhä et al. 2015) in general, but also with regard to deaccessions. ${ }^{4}$

We wanted the issues of deaccessioning to be widely visible and discussed in the museums sector in Finland. An essential aspect was therefore a survey on deaccessioning procedures and their main problems that was carried out at the beginning of our project in 2014. Issues of deaccessioning were also addressed in some twenty seminars and training events.

The initiative was funded by the Finnish Ministry of Education and Culture, and the Finnish Museums Association included our publications in its web publications series. We are also grateful to the National Museum of Finland, the Finnish National Gallery and to the National Board of Antiquities for participating in our work and for providing their support in the steering group of our project. 


\section{Minna Sarantola-Weiss \& Emilia VÄsti}

134

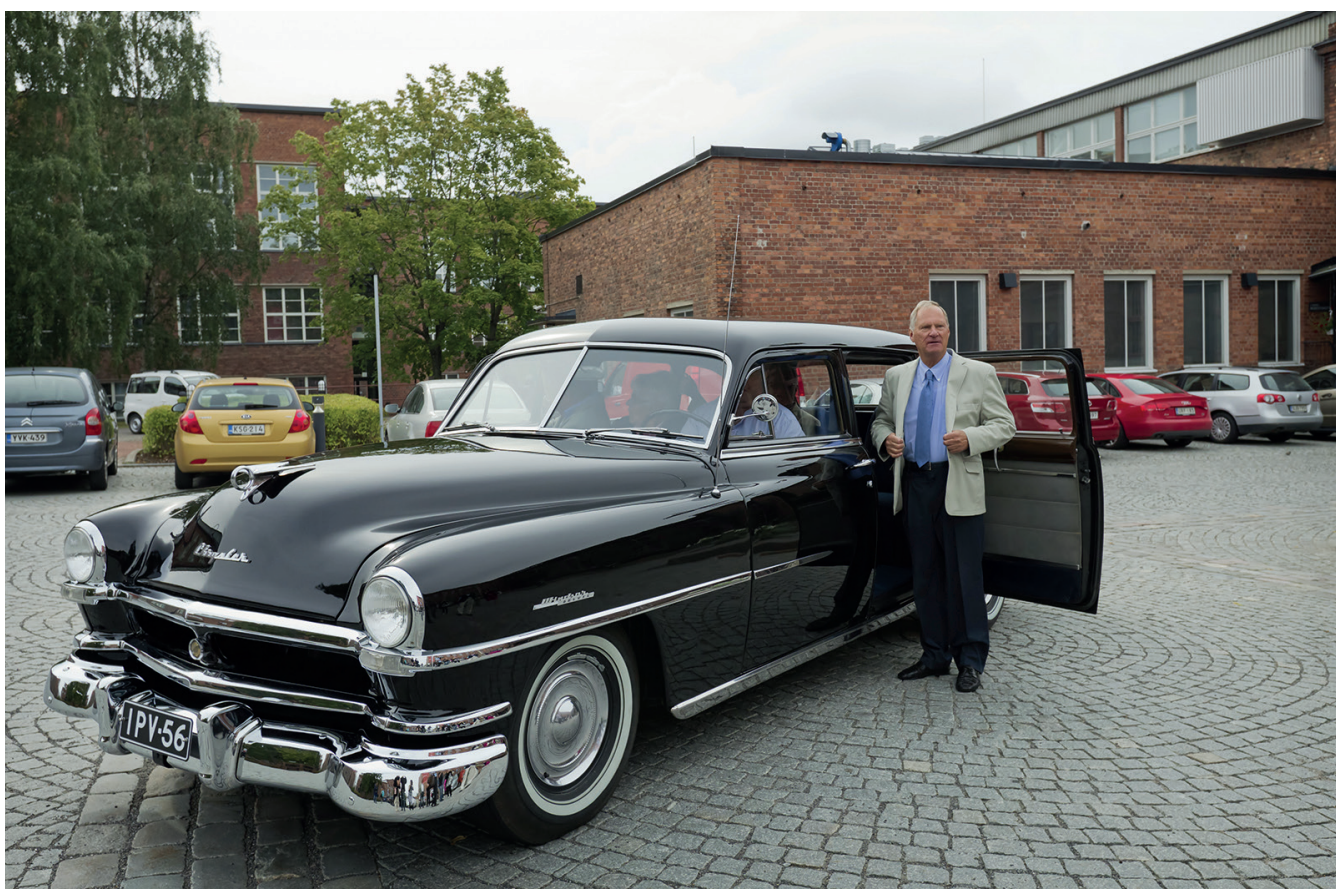

Fig. 1. Deaccessioned vehicle can be restored to use. This deaccessioned 1951 Chrysler Windsor de Luxe was restored for official representation purposes for the City of Tampere. Timo P. Nieminen, Mayor of Tampere 2007-2012 stepping into the car. Photo: Tampere Museums.

\section{STARTING POINTS}

Discussion on deaccessioning and its various forms is a topical issue in museums in the 2010s (Davies 2011). Despite this, the term deaccession still has a slightly negative tone, being often associated only with disposing of material by destroying it. We disagree and maintain that the most important aim of deaccessioning is to develop and refine museum collections. The goal must be collections that are full of significance to be used and developed methodically together with the communities that own them.

We have thus considered deaccessions as part of collections management and the work of developing the quality of collections.
We want to emphasise that considerations of deaccessioning should already be present when accessioning decisions are made. The related process should take into account the lifespan of the items in the museum's collections. What does this specific example of the cultural heritage require in terms of collections management and care, not only at the time of acquisition but also in the future? And in particular, what significance and meanings are collected for the future along with the object and how is this knowledge transmitted to the next generations of museum professionals?

In a considerable number of cases, deaccessions proceed from the needs of storage facilities: relocation, unsuitable ambient 
conditions or the need for more space. These grounds with reference to facilities are almost always also of an economic nature. The importance of economic considerations in deaccessioning decisions is difficult from an ethical point of view, but needs nonetheless to be explicitly discussed.

The updating and changes of collections management policy are another important point of departure. The aim of a functioning deaccessioning policy must be to permit acquisitions and the allocation of resources in accordance with collections management policy. Above all, however, the goal should be a developing museum collection of high quality and easy accessibility that will serve both its users and its owners well.

Our work took as its point of departure the ICOM Code of Ethics. The code provides a good starting point for considering deaccession. At the same time, however, it is of general scope and does not consider matters such as copyright issues or the need for museums to engage their communities.

Our most important practical model was the Disposal Toolkit web publication of the Museums Association of Great Britain (2008, revised version 2014). In the project, we also studied the British Find an Object and the Dutch herplaatsingdatabase collections transfer forums to investigate opportunities and the need to develop a similar Finnish service.

The practical basis for our work consisted of 14 case studies carried out by the participating museums with a wide range of different questions on deaccessioning and methods of disposal. After these analyses, we prepared a process framework that museums can apply to their own needs. An integral part of the framework consists of the criteria for assessing the museum value, ethical aspects and legality of suggested deaccessioning and for planning 135 deaccessioning processes. All the case studies included an inventory of the collections or part of them. After the deaccessioning process, we have a better understanding of the significance and value of the remaining objects and collections.

\section{DeACCessioning in FinNish mUSEUms}

Attitudes to deaccessioning are indicated in the collections policies of the museums. Our study of the documents, however, did not directly answer the question of how and where deaccessioning was actually carried out.

Part of our project was therefore a webbased survey announced on the nationwide Museoposti (Museum Post) email list in June 2014. The survey charted what was felt to function well in deaccessioning, what was found to be problematic, what was felt to require solutions, and how our project could provide help in these matters. A total of 65 replies to the survey were received, and 59 persons noted that deaccessioning had been carried out in their museums during their careers there.

The respondents gave various arguments that were used in deaccessioning evaluation (Table 1), emphasising the importance of an overall assessment. A single reason, such as museum-educational needs or the existence of similar objects in other collections, was rarely regarded as sufficient grounds for such action. The national division of tasks in collecting and documenting had less influence than expected on the collections policies and deaccessioning decisions of museums in 2014, but the situation might have changed in 2016.

The methods of disposal applied in museums were similarly surveyed. The method that was mentioned most often, by over 90 per cent of 


\section{Minna Sarantola-Weiss \& Emilia VÄsti}

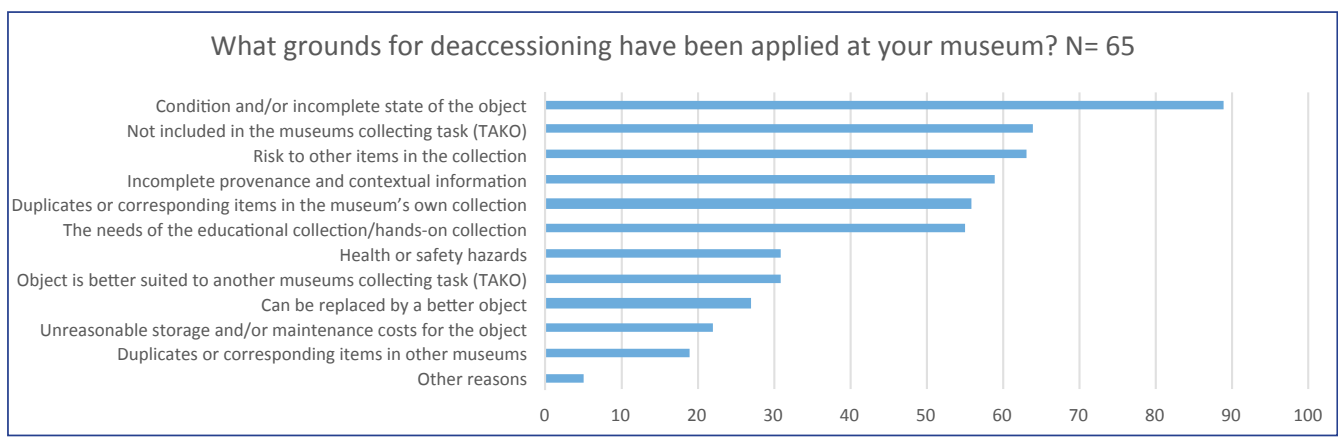

Table 1. What grounds for deaccessioning have been applied at your museum?

respondents, was to destroy the items. Various kinds of transfers are also carried out to a great deal, the most common ones mentioned being internal transfers. Almost 80 per cent of the respondents mentioned internal transfer to the museum's educational or hands-on collection as the method of disposal, and over half mentioned transfer to serve as exhibit props.

Approximately half (48 per cent) of the responding museums had practical experience of transferring deaccessioned objects to another professionally run museum. The transfer of items to a non-professional museum was considerably rarer ( 9 per cent). Our interpretation of the phenomenon is that it is regarded as unethical to solve deaccession problems of a professionally run museum by transferring objects to a nonprofessional museum.

\section{Attitudes to Deaccessioning}

The survey underlined the fact that attitudes to deaccessioning were felt to be a generation issue. It appears that the younger generation of museum professionals more readily accepted deaccessioning, regarding it as part of collections management.

Critical views are also important. The replies expressed wishes for discussion on the preser- vation of the cultural heritage as the task of museums, and noted as a risk of deaccessioning that the work of museums is turning into "short-term one-off activity". We have sought to take these risks into account. The assessment criteria of deaccessioning procedures that we have compiled urges a total assessment and also takes into account the criteria of the significance analysis method. Our aim is that the assessment should describe what an object contains and not only what it lacks.

The replies indicated concern that pressure from outside parties lacking knowledge of the principles and stages of collections management could lead to wrong decisions and skewed collections. "Cutbacks are made to the funding. In strained situations orders concerning deaccessioning or receiving collections can come from surprising parties, and the museum can be at a loss as to what to do when, for example, the top-level leadership of the municipality demands something that is against the museum's regulations."

We wish to stress that deaccessioning should be understood above all as a means of collections management and care (Vilkuna 2000:92, Kostet 2007:157-160, Pulkkinen 2013:129). Transferring an object to another collection can ensure better opportunities for it to be on 
display and better conditions than previously for its preservation. When objects prone to risk are removed, resources can be focused on accessions for the museum's core collection and the remaining collection can be ensured better care and secure conditions. The safety of the museum staff and museum visitors will also improve. It is also worth bearing in mind that the cultural lifespan of a deaccessioned object will not end with its physical removal. According to Peter van Mensch, objects will remain remembered or documented past their physical lifespan (van Mensch 1992, Häyhä et al. 2015, Robbins 2016:98-101).

\section{DOES DEACCESSIONING WORK?}

Many respondents consider deaccessioning to be a useful tool. Cases where the keeping of objects involved risks for other items and health were mentioned as the simplest for deaccession, as well as objects in unequivocally poor condition.

Freeing up storage space in concrete terms was an impetus for deaccessioning to make work more efficient and safer for both objects and personnel. The respondents also recognised the benefits for the quality of the remaining collection. "When the objects of the thematic area in question are properly studied as the basis of a deaccession proposal, the situation for the whole group of objects is better."

Transferring objects to another museum as a means of disposal was commended in the survey. The positive effects of the TAKO network were particularly noted: "I have donated material that does not belong to our division of collecting tasks to a museum where it would belong according to TAKO. The parties involved have been very satisfied."

The respondents urged their colleagues to apply effort to jointly develop the deaccessioning process and practices of their own museum and to make active use of them. Comparisons of the deaccessioning process with the museum's other processes, the acquisition of material in particular, were regarded as important. The respondents stated that problems arising in deaccessioning had been a practical reminder of an increasingly critical attitude to accessions to the collection.

\section{THE ETHICS OF DEACCESSIONING AND THE FINALITY OF DECISIONS}

The ethical and moral aspects of deaccessions were considered to a great extent in the replies. It was asked whether museums are entitled to deaccess, what grounds are valid, and who is entitled to make these decisions in museums.

Particular causes of uncertainty were: the finality of deaccessions, promises given to

Fig. 2. Building conservator Petra Heinonen and museum technician Jonas Haili repacking an inventoried tiled stove. The Helsinki City Museum's deaccessioning policy was amended in 2015 to permit the recycling or sales of donations from other parties than private individuals. Photo: Helsinki City Museum/Jaana Maijala 2014.

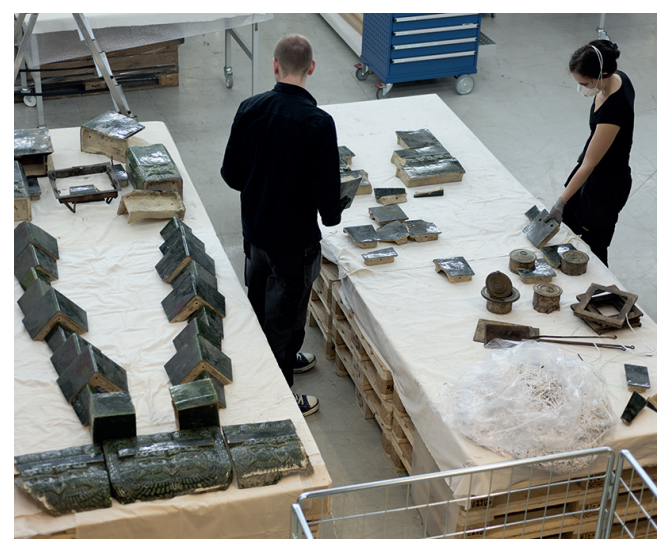


138 donors to keep the material, and the fear of losing the trust of the public, of future generations. The fear of losing trust and the desire to avoid conflicts emerged particularly in local museums where donors or their family are well known. As a result, "there is no courage to make deaccessions that would lead to altercations".

Problems of donation terms were also mentioned. The older accession forms do not necessarily mention the museum's right to deaccess the material or to pass it on to third parties. The replies show that museums do not have any definite arguments for a situation in which donors or their heirs might enquire about a deaccessioned donation. On the other hand, we may ask how much respect for the opinions of earlier owners/donors is an obligation created within the field itself.

Some museum professionals were afraid of being marked in professional circles or in their own working community: "Deaccession has to be argued for much more than acquisition, even to one's own colleagues. It is still regarded as a failure, loss or unprofessionalism."

\section{THE CHALLENGES OF THE DEACCESSIONING PROCESS}

Some respondents felt that the deaccessioning process was hindered and slowed by the difficulties of obtaining information on the collections of other museums. Problems of acquiring information concerned situations where the transfer of an object to another museum was considered, but also cases where the mutual correspondence of collections was to be ensured at the national level. This may reflect the fact that the FINNA information search service and the division of tasks in collecting and documenting between museums are both relatively new tools and processes and have not yet become established in all museums.

Several respondents mentioned deaccessions being made difficult or directly prevented by the lack of available working hours and funds. "A thorough deaccessioning process will have the result that deaccessioning needs will be recorded but there will be no time to carry out deaccessioning. The deaccessioning decision can require much more time than cataloguing an object." It is essential that the museum personnel, management and funding parties understand that the appropriate deaccessioning process will require resources and that there are no free quick solutions.

The survey showed the lack of contextual information to be both a reason for deaccessioning and an obstacle to it. The ICOM Code of Ethics calls for full understanding of the significance of an object. It is important for each museum to define what this means, with its own starting points in mind. Investigations, however, do not always lead to results and the significance of an object can change over time. We find it crucial to keep the extent of investigation in relation to available resources and to define what information is essential for the object in question. As a solution, the Disposal Toolkit (2008 \& 2014) suggests assessing the risks of disposal or deaccessioning (ethical issues, negative publicity etc.), which we regard as an excellent idea.

Emphasised in the replies was concern over how museum audiences, future generations, colleagues, donors and their heirs will react to deaccessioning. We believe that up-todate collections policies and deaccessioning processes are the tools for responding to these questions. They give us the arguments, and in this connection they help museums take the expert role in the management of collections and deaccessioning. 
WHAT DID WE LEARN?

We believe we succeeded well in our central goal of implementing and enhancing analytical professional discussion on deaccessioning. The concrete result of the project is the process framework. The framework mainly discusses the deaccessioning of physical museum objects and is adapted to the needs of museums of cultural history, but it can be equally applied to the needs of other types of museums and collections.

Replies to our survey and the experiences from our own case studies point to five themes in particular that should be taken into account when a museum assesses the realistic possibilities of deaccessioning. They are the museum's collections management policy, existing agreements and legal considerations, the motives for deaccessioning, and decisionmakers and resources. Internalising these principles and establishing processes within the museum organisation as a whole are preconditions for successful deaccessioning.

There is a difference between the ways in which cultural history museums and art museums deaccession objects. An item deaccessioned from a cultural-historical collection can be used, for example, for museum-educational purposes or as a prop in an exhibition. Parts or samples can be taken for conservation needs or material studies. Otherwise, the object is removed from the museum premises. Our discussions show that in art museums, pieces that can no longer be displayed because of their poor condition or for instance suspected forgery are often still kept in the collection. The destruction of a piece or other means of disposal are avoided, and the deaccessioned work or parts of it are often stored in the museum even after it has been decided to deaccession it and the destruction of works has been recorded as a possible method of disposal in the collections management policy.
We want to challenge art museums to consider why deaccessioned objects are kept in museums. What are the grounds for keeping works, and for whom or what are they kept?

In art museums, the deaccessioning cases that were regarded as most acceptable and most likely were those in which the artworks were assumed to have a short lifespan, for example because of their materials. Museums of cultural history are also increasingly required to consider the lifespan of objects. The experiences of keeping modern materials, rubber and plastics, have shown that it is necessary to accept the limits of an object's lifespan also in museums of cultural history. There are things to be jointly learned in procedures and models for solutions.

\section{EXPERIENCES OF THE SALE OF COLLECTION ITEMS IN FINLAND}

Attitudes to the ethical nature of various means of disposal vary in different countries. In Finland, a fairly common method of disposal is to destroy deaccessioned objects and to recycle them as material. The Disposal Toolkit publication, however, states that only hazardous objects should be removed by destroying them. An alternative is to sell items, which for the time being has been regarded in much more negative terms in Finland. The replies to our survey on disposal show, however, that Finnish museums have also begun to discuss whether the sale of an object would be a more ethical means of disposal in a situation where it has reached the end of its lifespan in a museum, but could still have other value for use with regard to its condition.

In our project, we discussed the sale of objects mainly from the perspective of museums of cultural history. In our case studies, the items on sale were mass-produced everyday objects, 


\section{Minna Sarantola-Weiss \& Emilia VÄsti}

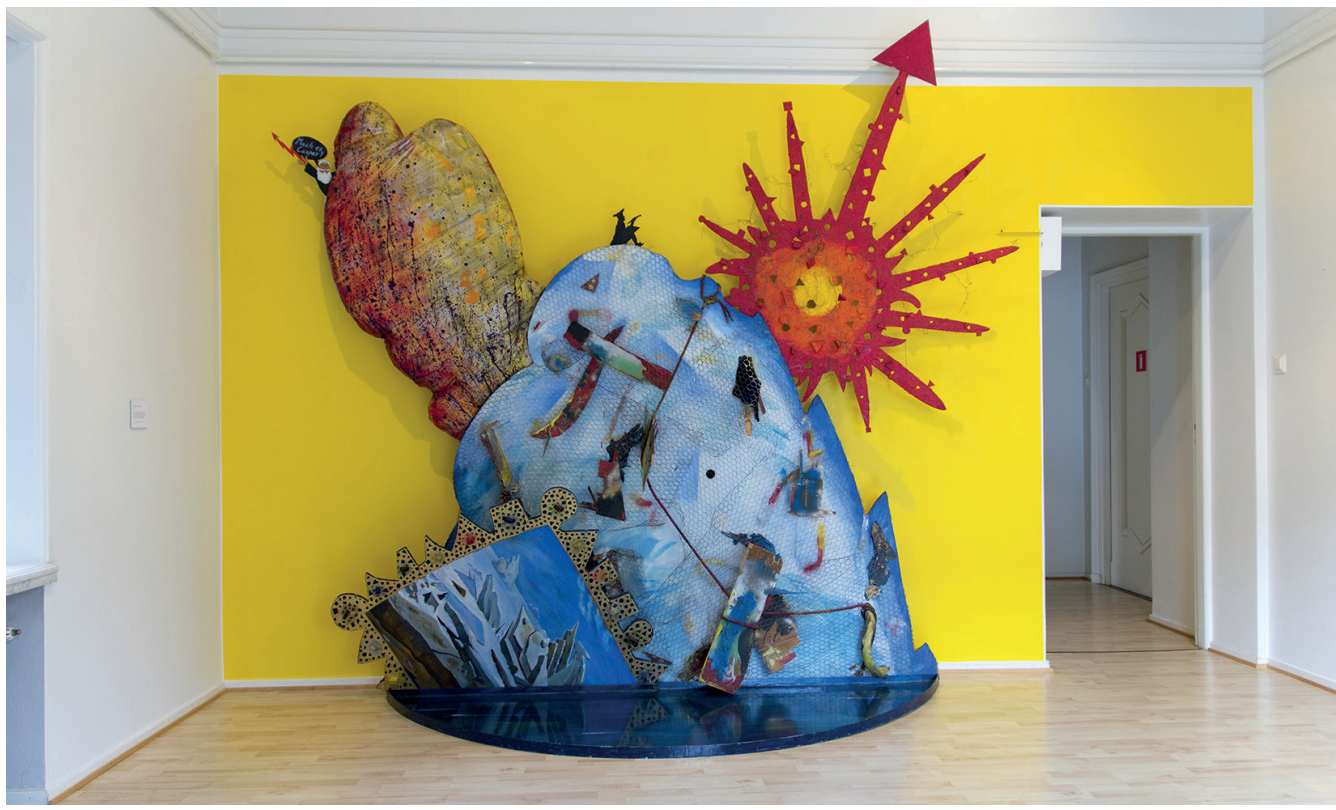

Fig. 3. Works of contemporary art are often doomed to disintegrate owing to the obsolescence of techniques or the incompatibility of materials. Jan-Erik Andersson's (b. 1954) installation The Romantic Painter Caspar David Friedrich's The Wreck of the Ship Called Hope 1821, in Ice-Cold Water (1986). The materials of the work consist of, at least, plywood, chipboard, steel tubing, chicken wire, rope, glass, artificial fur, wire, foam rubber, cotton fabric and acrylic paint. Photo: Aboa Vetus \& Ars Nova Museum/Jari Nieminen 2015.

cars and tiled stoves, not unique works of art. In both cases, there were reasons of collections management policy and the use of storage space behind deaccessioning.

As far as we know, works of art have not been sold from the collections of Finnish art museums. Sale as a form of deaccessioning was an alien concept for the art museums participating in our project as well, for the very reason that they did not regard deaccessioning for reasons of collections management policy as timely measures for their own collections. Before engaging in sales, they should carefully consider the consequences from the perspective of the artists, the art field and the museum collection.

There is obviously need for discussion on the ethics of selling objects, elucidation of related contractual rights and the sharing of practical experiences of selling museums objects. In our project, we were not able to formulate a recommendation, nor did we have authorisation for it.

\section{Conclusion}

For the time being, there are no jointly accepted instructions for deaccessioning in the Finnish museums community, nor is there a body that would monitor the ethical nature of deaccessioning in general, and through sales from collections in particular. As there are no detailed nationally approved instructions, particular responsibility and 
The case studies carried out in the project:

Justifications for deaccessioning of tiled stoves with reference to collections management policy (The Helsinki City Museum)

Practical issues in emptying storage facilities (The Museum of Technology)

Participatory involvement of tram enthusiasts in a significance analysis of the tram collection (The Helsinki City Museum)

Assessment criteria in the deaccessioning process of utility textiles (The Historical Collections of the Tampere Museums)

The use of deaccessioned utility textiles in museum pedagogy (The Historical Collections of the Tampere Museums)

The joint evaluation of art by an art museum and a historical museum (The Historical Collections of the Tampere Museums and the Tampere Art Museum)

Donation terms as thresholds in deaccessioning (The Museum of Technology)

Modern materials and the lifespan concept of objects (The Historical Collections of the Tampere Museums)

The disposal and documentation of a concrete sculpture in public space (HAM - Helsinki Art Museum)

The effects of choices of material and lifespan on the deaccessioning process in the context of contemporary art (Aboa Vetus \& Ars Nova)

Transfer to another museum as a method of disposal (The Museum of Technology)

The problems and assessed practices of selling motor vehicles from museum collections (The Historical Collections of the Tampere Museums)

Selling of tiled stoves (The Kuopio Museums) careful consideration are required from museum professionals. Responsibility, however, should not be avoided. Although deaccessions are not necessary for developing all museum collections, this does not mean that deaccessioning policy, including the sale of objects, should not be addressed and developed. What, for example, should be done if a museum faces outside pressure to deaccession for economic reasons? The critical questions of decision-makers need to be answered, and museums must be able to present coherent arguments for their core operations in order to safeguard their collections.

\section{Notes}

1. In her recent doctoral dissertation, the art historian Nina Robbins (2016) discusses deaccessioning from Finnish art museums with particular reference to museum value.

2. http://tako.nba.fi/index. Accessed 27 December 2016.

3. https://www.finna.fi/?lng=en-gb. Accessed. 27 December 2016.

4. For more discussion see Russell et al. 2009 and Versloot 2014.

\section{LITERATURE}

Davies, Peter (ed.) 2011. Museums and the Disposal Debate. A Collection of Essays. Edinburgh: MuseumsEtc.

Disposal Toolkit. Guidelines for Museums

2008. Museums Association. http://www. museumsassociation.org/download?id=15852

(accessed 10 April 2016)

Disposal Toolkit. Guidelines for Museums

2014. Museums Association. http://www.

museumsassociation.org/download?id=1075416

(accessed 27 December 2016)

Ekosaari, Maija, Sari Jantunen \& Leena Paaskoski 
2014. A Checklist for Museums Collections Policy. The National Board of Antiquities' Guidelines and Instructions 9. National Board of Antiquities. http://www.nba.fi/fi/File/2404/museumcollections-management-policy.pdf (accessed 27 December 2016)

Häyhä, Heikki, Sari Jantunen \& Leena Paaskoski 2015. Merkitysanalyysimenetelmä. Helsinki: Suomen museoliitto. (Suomen museoliiton julkaisuja 64.)

Kostet, Juhani 2007. "Kokoelmien muodostuminen." In Pauliina Kinanen (ed.). Museologia tänään. Museologian peruseet. Helsinki: Suomen museoliitto, 136-162. (Suomen museoliiton julkaisuja 57.)

Pulkkinen, Ritva 2013. Poistot museoiden kokoelmahallinnassa. Pro gradu-tutkielma. Informaatiotutkimus ja interaktiivinen media. Tampere: Tampereen Yliopisto.

Reed, Caroline 2012. Reviewing: Significance 2.0.

The Collections Trust, 2012. http://www. collectionstrust.org.uk/item/1196-reviewingsignificance-2-0 (accessed 27 December 2016)

Robbins, Nina 2016. Poisto museokokoelmasta museologinen arvokeskustelu kokoelmanhallinnan määrittäjänä [Museum Collection Disposal - The role of museological value discussion in collections management.] Jyväskylä: Jyväskylän Yliopisto.

Russell, Roslyn \& Kylie Winkworth 2009. Significance 2.0. A Guide to Assessing the Significance of Collections. Rundle Mall: Collections Council of Australia. https://www.arts.gov.au/what-we-do/ museums-libraries-and-galleries/significance-20 (accessed 27 December 2016)

Sarantola-Weiss, Minna \& Emilia Västi 2016:

Deaccessioning. Sharing Experiences from Finland. Helsinki: Finnish Museums Association. http:// www.museoliitto.fi/index.php?k=12613 (accessed 27 December 2016)

van Mensch, Peter 1992. Towards a Methodology of Museology. PhD thesis. Zagreb: University of Zagreb.
Västi, Emilia \& Minna Sarantola-Weiss (eds.) 2015. Kokoelmapoistojen hyvät käytännöt. Helsinki: Suomen museoliitto. (Suomen museoliiton julkaisuja 65.) http://www.museoliitto.fi/ kokoelmapoistot (accessed 27 December 2016) Västi, Emilia \& Minna Sarantola-Weiss (eds.) 2016. Kokoelmapoistojen yhteiset käytännöt. Helsinki: Suomen museoliitto. (Suomen museoliiton julkaisuja 71.) http://www.museoliitto.fi/ kokoelmapoistot2 (accessed 27 December 2016)

Versloot, Anne (ed.) 2014. Assessing Museum Collections. Collection Valuation in Six Steps. Amersfoort: Cultural Heritage Agency. http://cultureelerfgoed.nl/sites/default/files/ publications/assessing-museum-collections.pdf (accessed 27 December 2016)

Vilkuna, Janne, 2000. “Kestämätön kehitys.” In Janne Vilkuna (ed.). Näkökulmia museoihin ja museologiaan. Ethnos toimite 10.

Minna Sarantola-Weiss Adjunct professor at Helsinki University Head of research, Helsinki City Museum minna.sarantola-weiss@hel.fi

Helsingin kaupunginmuseo/

Helsingfors stadsmuseum

Keski-Uudenmaan maakuntamuseo/

Mellersta Nylands landskapsmuseum

$P L / P B 4300$

SF- 00099 Helsingin Kaupunki, Finland

Emilia Västi, Curator, project coordinator

Museum of Technology

emilia.vasti@tekniikanmuseo.fi

\section{Translation:}

Jüri Kokkonen 